\title{
СТАНДАРТИ ФОРМУВАННЯ ДОСТАТНЬӦ̈ СУКУПНОСТІ ДОКАЗІВ У КРИМІНАЛЬНОМУ ПРОЦЕСІ
}

\author{
КРЕТ Галина Романівна - доктор юридичних наук, доцент, суддя Великої \\ Палати Верховного Суду \\ УДК 343.141 \\ DOI 10.32782/NP.2021.3.9
}

Статья посвящена раскрытти состояния нормативного закрепления и применения международнъих стандартов бормирования достаточной совокупности доказательств в уголовном процессе.

Раскрыт круг международньхх стандартов формирования достаточной совокупности доказательств, которьие находят прямое и опосредованное закрепление в отечественном уголовном процессуальном законе или основълваются на его нормах. В контексте исследования состояния нормативного закрепления стандарта доказъвания, согласно с которьим оченка доказательств с точки зрения их достаточности является обязанностью начиональных судов, раскрылтьи особенности ее установления судами первой, апелляицонной и кассационной инстанций.

Установлен круг международнъих стандартов формирования достаточной совокупности доказательств, применяемьх в практике отечественньгх судов. Обращено внимание на то, что стандарт доказъвания, согласно с которьлм совокупность доказательств должна характеризоваться иерархическим построением, нашел применение исключительно в судебной практике.

Наряду с международнъми стандартами бормирования достаточной совокупности доказательств, выделен еще один стандарт доказвивания, присущий отечественному уголовному процессу - ни одно доказательство не имеет заранее установленной сильл.

Ключевъе слова: стандартьи доказъвания, международнъие стандарть доказвьвания, международнъе стандартьл бормирования достаточной совокупности доказательств, достаточность доказательств.

\section{Постановка проблеми}

Поняття достатності доказів як системної процесуальної властивості, яка характеризує їх сукупність, необхідну для ухвалення відповідного процесуального рішення, не знайшло нормативного закріплення у вітчизняному кримінальному процесуальному законі. Водночас, вагомий вплив на розвиток вітчизняної моделі достатності доказів здійснюють міжнародні стандарти формування достатньої сукупності доказів, напрацьовані в практиці ЄСП час надання ним оцінки дотриманню національними судами положень ст. ст. 3 і 6 Конвенції про захист прав людини і основоположних свобод від 04.11.1950р., які гарантують заборону катування та право на справедливий судовий розгляд. До числа міжнародних стандартів формування достатньої сукупності доказів належать: 1) оцінка доказів 3 точки зору їх достатності є обов'язком національних судів; 2) неможливість надання судом апеляційної інстанції іншої оцінки змісту доказів, досліджених судом першої інстанції (іншого їх тлумачення), за умови, якщо вони не були предметом безпосереднього дослідження під час апеляційного розгляду; 3) неприпустимість обгрунтування судового рішення, яким встановлюється винуватість обвинуваченого у вчиненні кримінального правопорушення, на основі єдиного доказу; 4) докази, які використовуються для ухвалення судового рішення, повинні перебувати у тісному логічному взаємозв'язку; 5) взаємозв'язок доказів повинен носити об'єктивний характер; 6) сукуп- 
ність доказів повинна характеризуватися ієрархічною побудовою.

\section{Аналіз останніх досліджень і публікацій}

Розкриттю поняття та системи міжнародних стандартів доказування i дослідженню змісту, сфери і механізму використання окремих 3 них у кримінальному провадженні присвячені наукові праці В.Д. Басая, В.В. Вапнярчука, I.В. Гловюк, В.О. Гринюка, С.О. Ковальчука, В.І. Мариніва, М.А. Погорецького, Х.P. Слюсарчук, А.С. Степаненка, В.М. Трофименка, О.Г. Шило та інших вітчизняних i зарубіжних учених. Водночас, нормативноправові аспекти закріплення міжнародних стандартів формування достатньої сукупності доказів у вітчизняному кримінальному процесуальному законі та їх застосування в практиці національних судів не знайшли належного висвітлення в доктрині кримінального процесу.

\section{Формулювання мети статті}

Метою цієї статті є розкриття стану нормативного закріплення та застосування міжнародних стандартів формування достатньої сукупності доказів у кримінальному процесі.

\section{Виклад основного матеріалу}

Міжнародні стандарти формування достатньої сукупності доказів здебільшого використовуються в практиці національних судів і грунтуються на нормі ч. 1 ст. 94 КПК, якою законодавець покладає на слідчого, прокурора, слідчого суддю, суд оцінити сукупність зібраних доказів з точки зору достатності та взаємозв'язку для прийняття відповідного процесуального рішення [1]. У результаті здійснення оцінки доказів з точки зору їх достатності зазначені суб'єкти доказування встановлюють притаманність наявній сукупності доказів ознак системи. Система доказів, які використовуються для ухвалення процесуальних рішень, повинна відповідати вимогам до неї, якими є: 1) повнота системи доказів, яка свідчить про всебічне та повне встановлення за їх допомогою всіх обставин, які становлять предмет доказування; 2) однозначність системи доказів, яка вказує на можливість обгрунтування на їх основі єдиного висновку щодо обставин, які становлять предмет доказування, та виключає іншу інтерпретацію останніх; 3) узгодженість доказів, яка свідчить про відповідність змісту одних доказів, що використовуються для встановлення конкретної обставини, яка входить у предмет доказування, змісту інших доказів, використовуваних для іiі встановлення, а також про їх відповідність змісту доказів, що використовуються для встановлення інших обставин.

Вказані вимоги становлять основу для виокремлення стандартів достатності доказів, а саме: 1) докази повинні повно встановлювати обставини предмета доказування, для підтвердження яких вони використовуються в процесуальному рішенні; 2) докази, які використовуються в процесуальному рішенні, мають забезпечувати обгрунтування єдиного висновку щодо обставин, які становлять предмет доказування; 3) докази, які використовуються для ухвалення судового рішення, повинні бути узгоджені між собою та перебувати у тісному взаємозв'язку.

У ході судового розгляду оцінка доказів 3 точки зору їх достатності покладається на суд (ч. 1 ст. 94 КПК), що повною мірою відповідає міжнародному стандарту формування достатньої сукупності доказів, відповідно до якого вона є обов'язком національних судів. Обов'язок оцінити докази з точки зору достатності законодавець покладає лише на суди першої та апеляційної інстанцій, які надають, оцінюють достатність сукупності безпосередньо досліджених ними доказів. При цьому здійснена судом першої інстанції оцінка доказів, як вказує С.О. Ковальчук, не є обов'язковою для суду апеляційної інстанції, оскільки останній, грунтуючись на результатах безпосереднього дослідження доказів, вправі дати їм власну оцінку. У разі, якщо судом апеляційної інстанції дослідження доказів не проводилося, здійснювана ним оцінка доказів обмежується їх оцінкою судом першої інстанції [2, с. 387] та повинна відповідати їй. Такий підхід узгоджується з правовими позиціями Верховного Суду, який, зокрема, в постанові від 17.05.2018 р. у справі № 480/1877/16-к зазначає, що згідно з доктринальними положеннями кримінального процесуального права при апеляційному перегляді в суду не виникає обов'язку досліджувати всю сукупність 


\section{Кримінальне право, кримінальний процес та криміналістика}

доказів 3 дотриманням засади безпосередності, якщо він по-новому (інакше) не тлумачить докази, отримані в суді першої інстанції, однак якщо апеляційний суд переоцінює хоча б один доказ, здобутий у суді першої інстанції, він повинен безпосередньо дослідити всі інші докази з дотриманням вимог ст. 23 КПК [3].

Водночас, наведений підхід є дещо ширшим від сформованого у практиці ЄСП $\curlywedge$, який передбачає неможливість надання судом апеляційної інстанції іншої оцінки змісту доказів, досліджених судом першої інстанції (іншого їх тлумачення), за умови, якщо вони не були предметом безпосереднього дослідження під час апеляційного розгляду. Натомість вироблений підхід зумовлює необхідність безпосереднього дослідження змісту тих доказів, дослідження яких 6 недоцільним, наприклад у випадку визнання недопустимим доказу 3 огляду на відсутність процесуальної підстави його отримання - ухвала слідчого судді не відкрита в порядку ст. 290 КПК, слідча (розшукова) дія оформлена протоколом огляду місця події, хоча по суті проведено обшук, що передбачає необхідність отримання ухвали на його проведення, а також в інших випадках, коли підстава визнання доказу недопустимим є очевидною та не потребує дослідження його змісту, на що не звернув увагу суд першої інстанції.

Крім того, такий підхід зумовлює необхідність безпосереднього дослідження змісту тих доказів, яким апеляційний суд не дав іншої оцінки, ніж суд першої інстанції, однак сукупність яких не дає підстав для висновку про їх достатність для прийняття рішення, якого дійшов суд першої інстанції.

У цьому контексті досить обгрунтованою є позиція Чернівецького апеляційного суду, який в ухвалі від 12.09.2019 р. у справі№ 727/4888/16-к констатував, що протокол проведення негласної слідчої (розшукової) дії у виді візуального спостереження за ОСОБА_1 є єдиним, основним, невід'ємним і беззаперечним доказом спільної участі ОСОБА_3 з ОСОБА_1 та ОСОБА_2 у скоєнні крадіжки майна потерпілого ОСОБА_6 та який внаслідок невідкриття ухвали слідчого судді в порядку ст. 290 КПК є недопустимим доказом, інші покладені районним судом в основу обвинувального вироку докази щодо цього епі- зоду не можна визнати належними і достатніми для доведення винуватості ОСОБА_1, ОСОБА_3 та ОСОБА_2 у вчиненні злочину, передбаченого ч. 3 ст. 185 КК, оскільки вони не вказують на факт, що обвинувачені ОСОБА_3 та ОСОБА_2 були обізнані про наміри ОСОБА_1 вчинити крадіжку майна потерпілого ОСОБА_6, а також на факт попередньої змови між ними, як того вимагає диспозиція цієї статті КК. Інших доказів для доведення винуватості ОСОБА_1, ОСОБА_3 та ОСОБА_2 за ч. 3 ст. 185 КК орган досудового розслідування та прокурор суду не надали [4]. Таким чином, суд апеляційної інстанції, безпосередньо не дослідивши ані протокол негласної слідчої (розшукової) дії, ані всі інші наявні у справі докази, обгрунтовано констатував їх недостатність для доведення винуватості двох осі6 у вчиненні інкримінованого злочину та відсутність кваліфікуючої ознаки вчинення злочину за попередньою змовою групою осіб щодо третьої особи.

При вирішенні питання про безпосередність дослідження доказів судом апеляційної інстанції потрібно виходити 3 декількох моментів. По-перше, суд апеляційної інстанції не може дати іншої оцінки змісту доказу (виправдувальної/обвинувальної), ніж та, яку дав суд першої інстанції, без його безпосереднього дослідження. По-друге, суд апеляційної інстанції, надаючи іншу оцінку доказу в аспекті його процесуальної властивості (належності, допустимості, достовірності), зобов'язаний безпосередньо дослідити цей доказ у випадках, коли така оцінка випливає з його змісту, а також безпосередньо дослідити інші докази, якщо переоцінка одного може вплинути на оцінку інших, але також з позиції їх змісту. По-третє, суд апеляційної інстанції не зобов'язаний безпосередньо досліджувати всю сукупність доказів у випадках, коли після надання іншої оцінки доказу (доказам) він констатує очевидну достатність/недостатність сукупності доказів, іншої оцінки яким він не надавав, для прийняття процесуального рішення.

Суд касаційної інстанції, відповідно до ч. 1 ст. 433 КПК, не має права досліджувати докази, встановлювати та визнавати доведеними обставини, що не були встановлені в оскарженому судовому рішенні [1], у зв'язку з чим 
не наділений правом здійснювати їх оцінку, у тому числі з точки зору їх достатності. Звертаючи увагу на цю обставину, Верховний Суд в постанові від 26.02.2020 р. у справі№ 759/358/18 вказує, що в цьому провадженні, за умови підтвердження порушення права на захист під час впізнання, сукупність доказів, представлена стороною обвинувачення, має отримати оцінку суду з точки зору їх достатності для доведеності винуватості ОСОБА_1 в інкримінованому йому кримінальному правопорушенні, а докази, що входять у сукупність, і з точки зору їх достовірності. 3 огляду на зміст ч. 1 ст. 433 КПК вирішення таких питань знаходиться поза межами компетенції суду касаційної інстанції [5].

Аналізуючи положення ч. 1 ст. 433 КПК, потрібно виокремити декілька аспектів щодо можливості/неможливості оцінки достатності доказів судом касаційної інстанції. Перш за все, необхідно зазначити, що вказана норма містить пряму заборону щодо оцінки достовірності того чи іншого доказу судом касаційної інстанції, а також заборону дослідження доказів, що має наслідком неможливість їх оцінки з точки зору належності. Разом з тим, наведена норма передбачає, що суд касаційної інстанції перевіряє правильність застосування судами першої та апеляційної інстанцій норм процесуального права, тобто по суті констатує порушення норм КПК, у тому числі й тих, що стосуються встановлення допустимості/недопустимості доказу, на які суди першої та апеляційної інстанцій не звернули увагу. Оскільки прямої заборони щодо оцінки доказу з точки зору допустимості аналізована норма не містить, то очевидним $\epsilon$ те, що суд касаційної інстанції може визнати доказ недопустимим, що зумовлює необхідність надання ним оцінки усій іншій сукупності доказів $з$ точки зору достатності. Здійснюючи таку оцінку, суд касаційної інстанції повинен враховувати: 1) чи впливає визнання доказу недопустимим на необхідність дослідження інших доказів і можливість надання іншої оцінки окремим доказам у справі; 2) чи очевидною є достатність/недостатність сукупності інших доказів для прийняття кінцевого процесуального рішення .

Окрім того, цілком обгрунтованою є практика Верховного Суду щодо здійснення оцінки достатності доказів і закриття кримі- нального провадження у випадках, коли суди першої та апеляційної інстанцій на підставі наявних у справі доказів дійшли помилкового висновку про винуватість особи у вчиненні кримінального правопорушення. Так, Верховний Суд у постанові від 25.11.2019 р. у справі № 420/1667/18 зазначає, що єдиним доказом на підтвердження розміру матеріальних збитків, завданих товариству 3 обмеженою відповідальністю «Топаз» протиправними діями засуджених ОСОБА_1 і ОСОБА_2, є довідки зазначеного товариства щодо вартості викраденого майна... За обставин справи, тільки шляхом залучення експерта і на підставі його висновку в цьому кримінальному провадженні могла бути встановлена вартість викраденого майна та розмір матеріальних збитків. На порушення вимог п. 6 ч. 2 ст. 242 КПК сторона обвинувачення не вчинила процесуальних дій із залучення експерта. Таким чином, суди першої та апеляційної інстанцій належним чином не встановили такий елемент складу злочину, як розмір шкоди, завданої кримінальним правопорушенням. Надані стороною обвинувачення, досліджені й оцінені судами першої та апеляційної інстанцій докази не є належними і достатніми, щоб зробити висновок про вартість майна, яке було предметом замаху на крадіжку, у вчиненні якого обвинувачувалися ОСОБА_1 і ОСОБА_2, та про розмір матеріальної шкоди [6].

На відміну від ЄСП $\Lambda$, який вказує на неприпустимість обгрунтування судового рішення, яким встановлюється винуватість обвинуваченого у вчиненні кримінального правопорушення, на основі єдиного доказу, вітчизняний законодавець прямо не закріплює такої вимоги. Водночас вона значною мірою грунтується на нормах ч. 1 ст. 94 КПК у частині оцінки судом з точки зору достатності саме сукупності зібраних доказів і ч. 3 ст. 370 КПК, що визнає обгрунтованим рішення, ухвалене судом на підставі об'єктивно з'ясованих обставин, які підтверджені доказами, дослідженими під час судового розгляду й оціненими судом відповідно до ст. 94 КПК [1].

У практиці Верховного Суду обгрунтування судами першої та апеляційної інстанцій обвинувального вироку на основі єдиного доказу визнається істотним порушенням вимог кримінального процесуального закону, що 


\section{Кримінальне право, кримінальний процес та криміналістика}

призводить до його скасування та закриття кримінального провадження на підставі п. 3ч. 1 ст. 284 КПК. Так, у постанові від 29.03.2018 р. у справі № 459/2045/15-к Верховний Суд зазначає, що обвинувальний вирок щодо засуджених за епізодом щодо потерпілої ОСОБИ_10 грунтується на ії показаннях, зі змісту яких убачається, що вона бачила трьох осіб чоловічої статі, котрі ї̈ пограбували, проте не вказала на їх особи; а також даних слідчого експерименту від 23.06.2015 р. $з$ відео- та фотофіксацією до них, у ході якого ОСОБА_5 та ОСОБА_6 добровільно відтворили обставини пограбування ОСОБА_10. При цьому апеляційний суд визнав дані протоколу вказаної слідчої (розшукової) дії недопустимим доказом. За таких обставин, визнавши, що єдиним належним і допустимим доказом винуватості засуджених за вказаним епізодом є показання потерпілої, яка не вказала на їх особи як виконавців вчиненого щодо неї злочину, суду апеляційної інстанції належало скасувати вирок місцевого суду в цій частині і закрити кримінальне провадження на підставі п. 3 ч. 1ст. 284 КПК у зв'язку з невстановленням достатніх доказів для доведення винуватості особи в суді і вичерпанням можливостей їх отримати, але цього зроблено не було [7].

На нормі ч. 1 ст. 94 КПК, яка зобов'язує суд здійснити оцінку сукупності зібраних доказів $з$ точки зору їх взаємозв'язку для прийняття відповідного процесуального рішення [1] грунтується напрацьований ЕСПЛ стандарт формування достатньої сукупності доказів, відповідно до якого докази, що використовуються для ухвалення судового рішення, повинні перебувати у тісному логічному взаємозв'язку. Логічний взаємозв'язок доказів передбачає таке їх співвідношення, за якого кожен доказ, що входить у сукупність, узгоджується з іншими доказами, підтверджується цими доказами і не містить суперечностей та неузгодженостей з ними.

На відміну від дослідженого стандарту формування достатньої сукупності доказів, напрацьований $\mathrm{ECП \Lambda} \mathrm{стандарт} \mathrm{доказуван-}$ ня, згідно з яким взаємозв' язок доказів повинен носити об'єктивний характер, прямо не передбачений нормами вітчизняного кримінального процесуального закону. Водночас у них законодавець покладає на суд обов'язки зберігати об'єктивність і неупередженість(ч. 6 ст. 22 КПК), всебічно, повно та неупереджено дослідити всі обставини кримінального провадження (ч. 1 ст. 94 КПК) та підтвердити доказами об'єктивно з'ясовані обставини (ч. 3 ст. 370 КПК) [1]. Виходячи 3 наведених положень, суд зобов'язаний забезпечити обгрунтування судового рішення за допомогою сукупності доказів, яка перебуває в об'єктивному взаємозв'язку та не зазнає суб'єктивного впливу.

Поряд 3 цим, відповідно до ч. 2 ст. 94 КПК, жоден доказ не має наперед встановленої сили [1]. Недотримання судом цієї норми свідчить про його упередженість, внаслідок якої сукупність доказів, покладена в основу судового рішення, втрачає об'єктивний характер. На обов'язок судів дотримуватися вимог ч. 2 ст. 94 КПК звертає увагу Верховний Суд, який, надаючи у постанові від 21.06.2018 р. у справі № 349/651/16-к оцінку порушенням вимог кримінального процесуального закону, допущеним судом апеляційної інстанції, вказав, що судом не дотримано вимог ст. 94 КПК та допущено явну упередженість, оскільки, критично оцінюючи показання свідка ОСОБА_5 з тих підстав, що вона є дружиною обвинуваченого, суд взяв до уваги показання свідка ОСОБА_6, яка є дружиною потерпілого [8].

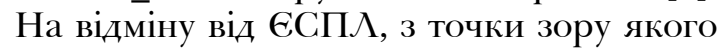
сукупність доказів повинна характеризуватися ієрархічною побудовою, вітчизняний законодавець у нормах кримінального процесуального закону не закріплює вказівок на ієрархічність доказів. Водночас національні суди використовують термін «ключовий доказ» i звертаються як до визначення такого доказу в конкретній справі, так і до встановлення його впливу на достатність доказів. Так, у постанові від 07.05.2019 р. у справі № 654/3305/15-к Верховний Суд вказує, що посилання у вироку та ухвалі на недопустимий доказ - протокол про результати аудіо-, відеоконтролю особи від 22.06.2015 р. i, як наслідок, виключення його з доказової бази жодним чином не впливає на правильність висновків судових інстанцій про вчинення ОСОБА_2 розбійного нападу на потерпілу ОСОБА_5 за наявності сукупності інших належних, допустимих та достовірних доказів його вини у вчиненні зазначеного злочину, розглянутих й оцінених судом. До- 
каз, який підлягає виключенню, не є прямим і ключовим у сукупності доказів, що підтверджують винуватість ОСОБА_2, а тому його виключення не створює передбачених ст. 412 КПК підстав для скасування судового рішення [9]. I, навпаки, неналежність, недопустимість або недостовірність ключового доказу призводить до визнання сукупності доказів недостатньою для ухвалення обвинувального вироку. Так, у постанові від 22.05.2019 р. у справі № 710/179/17 Верховний Суд зазначає, що суди першої та апеляційної інстанцій свій висновок про винуватість обгрунтували, зокрема, даними, встановленими 3 показань потерпілої ОСОБА_3, свідка ОСОБА_4, а також даними протоколу огляду місця події з фототаблицею до нього, протоколів проведення слідчих експериментів за участю свідків ОСОБА_4 і ОСОБА_5, висновків судово-медичних та судово-психіатричної експертиз. Також під час судового розгляду була допитана свідок ОСОБА_6, яка показала, що ОСОБА_4 їй казала, що ОСОБА 2 вбив ОСОБА 5, однак вона боялася давати такі показання, оскільки той погрожував, що буде таке саме, як з ОСОБА_2. Ці показання суди визнали недопустимим доказом, пославшись на те, що вони не були відкриті стороні обвинувачення як докази у ході виконання вимог ст. 290 КПК. Колегія суддів не може погодитися 3 висновком суду щодо недопустимості цього доказу iз зазначеної підстави. У судовому засіданні свідок ОСОБА_6 пояснила, що цю інформацію від ОСОБА_4 вона отримала влітку 2017 року під час спільних сільськогосподарських робіт, а захисту про це стало відомо лише в жовтні 2017 року, тобто під час судового розгляду. Враховуючи викладене, суд дійшов неправильного висновку про недопустимість такого доказу, як показання свідка ОСОБА_6. Сторона обвинувачення під час перехресного допиту не отримала від свідка інформацію, яка б ставила під сумнів достовірність ії показань, а також не надала будь-яких доказів, що спростовують іiі показання. За таких обставин, достовірність ключового доказу в цій справі - показань єдиного очевидця подій свідка ОСОБА_4-не була доведена стороною обвинувачення поза розумним сумнівом [10]. Водночас застосування наведеного стандарту формування достатньої сукупності доказів повинно чітко узгоджуватися 3 нормою ч. 2ст. 94 КПК.

\section{Висновки}

Проведене дослідження свідчить, що у вітчизняному кримінальному процесуальному законі знайшли закріплення три міжнародні стандарти формування достатньої сукупності: 1) оцінка доказів 3 точки зору їх достатності є обов'язком національних судів; 2) неможливість надання судом апеляційної інстанції іншої оцінки змісту доказів, досліджених судом першої інстанції (іншого їх тлумачення), за умови, якщо вони не були предметом безпосереднього дослідження під час апеляційного розгляду (при цьому в практиці національних судів наведений стандарт доказування знайшов більш широке тлумачення); 3) докази, які використовуються для ухвалення судового рішення, повинні перебувати у тісному логічному взаємозв' язку.

Інші міжнародні стандарти формування достатньої сукупності доказів або опосередковано закріплюються нормами КПК, або грунтуються на них. Так, неприпустимість обгрунтування судового рішення, яким встановлюється винуватість обвинуваченого у вчиненні кримінального правопорушення, на основі єдиного доказу як стандарт доказування грунтується на нормах ч. 1 ст. 94 і ч. 3ст. 370 КПК. Стандарт доказування, відповідно до якого взаємозв' язок доказів повинен носити об'єктивний характер, випливає зі змісту ч. 6 ст. 22 , ч. 1 ст. 94 і ч. 3 ст. 370 КПК.

Незалежно від форми їх нормативного закріплення (прямої чи опосередкованої), усі наведені стандарти доказування широко використовуються в практиці вітчизняних судів.

Міжнародний стандарт доказування, відповідно до якого сукупність доказів повинна характеризуватися ієрархічною побудовою, знайшов застосування тільки в судовій практиці.

Аналіз норм кримінального процесуального закону та сформованої на їх основі судової практики, поряд з міжнародними стандартами формування достатньої сукупності доказів, дозволяє виокремити ще один стандарт доказування, притаманний вітчизняному кримінальному процесу - жоден доказ не має наперед встановленої сили. 


\begin{tabular}{|c|}
\hline 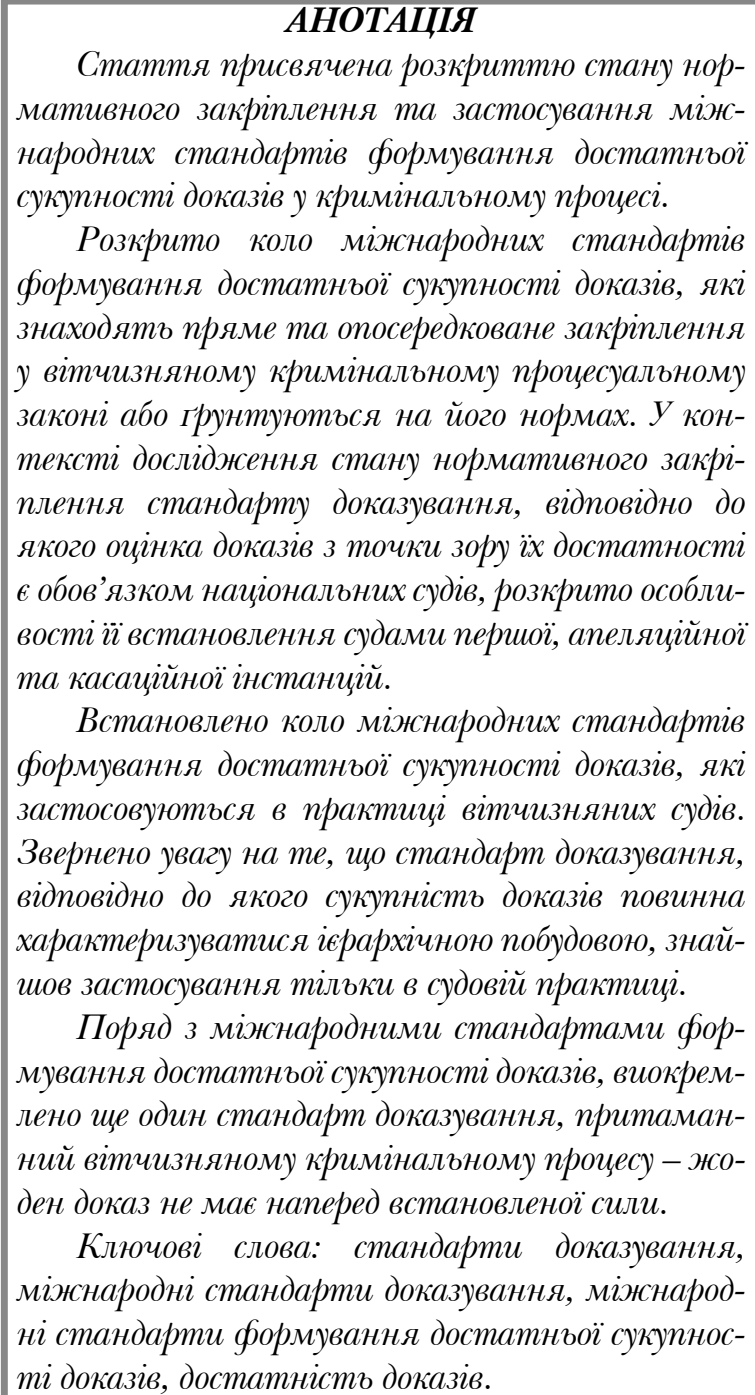 \\
\hline
\end{tabular}

\section{Лiтература}

1. Кримінальний процесуальний кодекс України від 13.04.2012 р. № 4651-VI. URL: http://zakon.rada.gov.ua/laws/show/465117.

2. Ковальчук С.О. Вчення про речові докази у кримінальному процесі: теоретико-правові та практичні основи: монографія. ІваноФранківськ: Супрун В.П., 2017. 618 с.

3. Постанова Верховного Суду від 17.05.2018р. усправі№480/1877/16-к. URL:http:// www.reyestr.court.gov.ua/Review/74262127.

4. Ухвала Чернівецького апеляційного суду від 12.09.2019 р. у справі№ 727/4888/16-к. URL: http://reyestr.court.gov. ua/Review/84207704.

\section{Наше право № 3, 2021}

The article is devoted to the disclosure of the state of statutory determination and application of international standards for the formation of a sufficient set of evidence in criminal proceedings.

The range of international standards for the formation of a sufficient set of evidence, which are directly and indirectly enshrined in the domestic criminal procedure law or based on its norms, is revealed. In the context of the study of the state of statutory determination of the standard of proof, according to which the evaluation of evidence in terms of their sufficiency is the responsibility of national courts, revealed the features of its establishment by courts of first, appellate and cassation instances.

$A$ set of international standards for the formation of a sufficient set of evidence used in the practice of domestic courts has been established. Attention is drawn to the fact that the standard of proof, according to which the set of evidence must be characterized by a hierarchical structure, has found application exclusively in judicial practice.

Along with international standards for the formation of a sufficient set of evidence, there is another standard of proof inherent in the domestic criminal process - no evidence shall have any predetermined value.

Key words: standards of proof, international standards of proof, international standards for formation of a sufficient set of evidence, sufficiency of evidence.

5. Постанова Верховного Суду від 26.02.2020 р. у справі № 759/358/18. URL: http:// www.reyestr.court.gov.ua/Review/87985435.

6. Постанова Верховного Суду від 25.11.2019 р. у справі № 420/1667/18. URL: http://reyestr.court.gov.ua/Review/86070671.

7. Постанова Верховного Суду від 29.03.2018 р. у справі № 459/2045/15-к. URL: http://reyestr.court.gov.ua/Review/73189758.

8. Постанова Верховного Суду від 21.06 .2018 р. у справі № 349/651/16к. URL: http://www.reyestr.court.gov.ua/ Review/74963614.

9. Постанова Верховного Суду від 07.05.2019 р. у справі № 654/3305/15-к. URL: http://reyestr.court.gov.ua/Review/81722323.

10. Постанова Верховного Суду від 22.05.2019 р. у справі № 710/179/17. URL: http://reyestr.court.gov.ua/Review/82001773. 